\title{
Effect of Various Diets on the Secretory Product of Midgut Cells of Drosophila auraria Larvae
}

\author{
V. K. Dimitriadis \\ Department of Biology, School of Science, Aristotelian \\ University, Thessaloniki, Greece
}

Accepted March 11, 1985

A number of studies have been done concerning the digestive activities of many insects. These activities were investigated using morphological features of midgut cells (see for example Ferreira et al. 1981, Rudin and Hecker 1982), biochemical determination (Terra et al. 1979, Ferreira and Terra 1980, Houseman and Downe 1981) or histochemical detection of digestive enzymes of midgut cells and midgut lumen (Beadle 1971, Walker et al. 1980). The elaboration and discharge of the digestive enzymes is generally supposed that follows the classically accepted scheme for these events (Palade 1975): i.e. the secretory enzymes are synthesized in the rough endoplasmic reticulum, are transferred by transitional elements to the Golgicomplexes where they are condensed and packaged into secretory granules which, in turn, are secreted at the apical region of the cells. Routine cytochemistry, however, is mostly a poor method in detecting positive reaction of various digestive enzymes on the secretory granules. The evidence for the digestive enzyme presence in the secretory granules would be greatly strengthened by cell franctionation and separation of the secretory granules, when digestive enzymes activities in these granules can be shown. However, is particularly difficult to apply the previous methodology in Drosophila midgut, because of its extremely size $(\approx 3.5 \mathrm{~mm}$ of the early third instar larvae). So, one of the purposes of the present study is to prove, using different diets, whether there is a relation between the secretory granules which are produced and secreted from the cells of the various midgut regions of the Drosophila auraria larvae and the digestive enzyme production of the same regions. But the main purpose of the present study is to investigate which of the midgut regions participate in protein, lipid and carbohydrate digestion.

Previous results (Dimitriadis and Kastritisis 1984) using morphological observations support the hypothesis that the gastric caeca and the anterior section of the posterior midgut of Drosophila auraria larvae are the main secretory regions. The mature secretory granules, which are produced by the Golgi complexes of the gastric caeca and by the midgut cells are continuously (without periodicity) secreted in the apical portion of the cells, in the space between adjacent microvilli.

\section{Materials and methods}

Larvae of Drosophila auraria (montium subgroup. melanogaster group) were reared on the culture medium described below. The stock used was obtained from the University of Texas at Austin Stock Center (Stock No. 3040.11b), and was 
originally collected from Kirishima, Japan.

\section{Feeding procedure}

Actively feeding larvae of the early third instar (about $90 \mathrm{~h}$ after oviposition) were selected and placed for $24 \mathrm{~h}$ in plastic cups, which contained the high carbohydrate, the high proteinate and the high lipid medium. "Normally fed" or "control larvae" were placed in plastic cups for $24 \mathrm{~h}$, which contained culture medium. The composition of the four different media are listed in Table 1. The concentration of components in each medium evaluated having as main criterion the increased concentration in starch, casein or cholesterol combined with the best preservation of the fine structure of the midgut cells. The composition of the media of Hosbach et al. (1972) was also considered.

Table 1. Concentration of components in the high carbohydrate, high proteinate and high lipid medium. The numbers are expressed as grams

\begin{tabular}{|c|c|c|c|c|c|c|c|c|c|}
\hline & $\begin{array}{c}\text { Maize } \\
\text { meal }\end{array}$ & Starch & Casein & $\begin{array}{c}\text { Choles- } \\
\text { terol }\end{array}$ & Glucose & Sucrose & Agar & $\begin{array}{l}\text { Dried } \\
\text { yeast }\end{array}$ & Water \\
\hline $\begin{array}{l}\text { Control } \\
\text { medium }\end{array}$ & 20 & & & & & 5 & 1.7 & 2.5 & 150 \\
\hline $\begin{array}{l}\text { High } \\
\text { carbohyd } \\
\text { medium }\end{array}$ & & 25 & & & 2 & & 2 & 3 & 40 \\
\hline $\begin{array}{l}\text { High } \\
\text { proteinat } \\
\text { medium }\end{array}$ & & & 25 & & 2 & & 2 & 3 & 50 \\
\hline $\begin{array}{l}\text { High lipid } \\
\text { medium }\end{array}$ & & & & 12 & 2 & 5 & 5 & 7 & 40 \\
\hline
\end{tabular}

\section{Electron microscopy}

The tissues were fixed in Karnovsky's fixative (Karnovsky 1965), postfixed in unbuffered cold $2 \% \mathrm{OsO}_{4}$, and stained with $0.5 \%$ uranyl acetate solution. Sections were cut using a Reichert Om U3 ultramicrotome, poststained with aqueous lead citrate and examined with a JEOL 100B electron microscope.

\section{Morphometric evaluation}

The number of secretory granules of the various regions of the midgut of Drosophila auraria larvae was estimated as already is described (Dimitriadis, 1985): 50 cells from every midgut region of 10 different "control larvae" and larvae reared on starch, casein and cholesterol diets were examined. The secretory granules in each cell were counted in the following manner: On the screen of the JEOL 100B electron microscope an area is inscribed in the shape of a parellelogram with dimensions which correspond to a $4.5 \times 3 \mu \mathrm{m}$ size, when the $\times 20,000$ magnification is used. The projection of this area was positioned on the cell's image at random, but always in contact with the apical microvilli. The number of granules inside the above area was counted and the procedure was then repeated for a similar area adjacent to the initial. The exact position of the new area was determined using as markers morphological characteristics of the cell. Thus the effective size of the counting area per cell was $9 \times 3 \mu \mathrm{m}\left(27 \mu \mathrm{m}^{2}\right)$. 
Mean values and standard errors of the number of the secretory granules were calculated and statistically compared (Student's t-test, significance level $2 p<0.01$ ).

\section{Results}

When early third instar larvae of Drosophila auraria fed on a diet rich in starch for $24 \mathrm{~h}$, a great increase in the number of the secretory granules produced in the anterior midgut was observed, as compared to the "control larvae". This increase is indicated by the high concentration of the secretory granules near the microvilli of the cells (Fig. 1, Table 2), i.e. just prior to their secretion (Fig. 2). Lower increase in the number of the secretory granules was, also, observed in the anterior section of the posterior midgut, while there was no detectable difference in the number of the secretory granules in the other midgut regions.

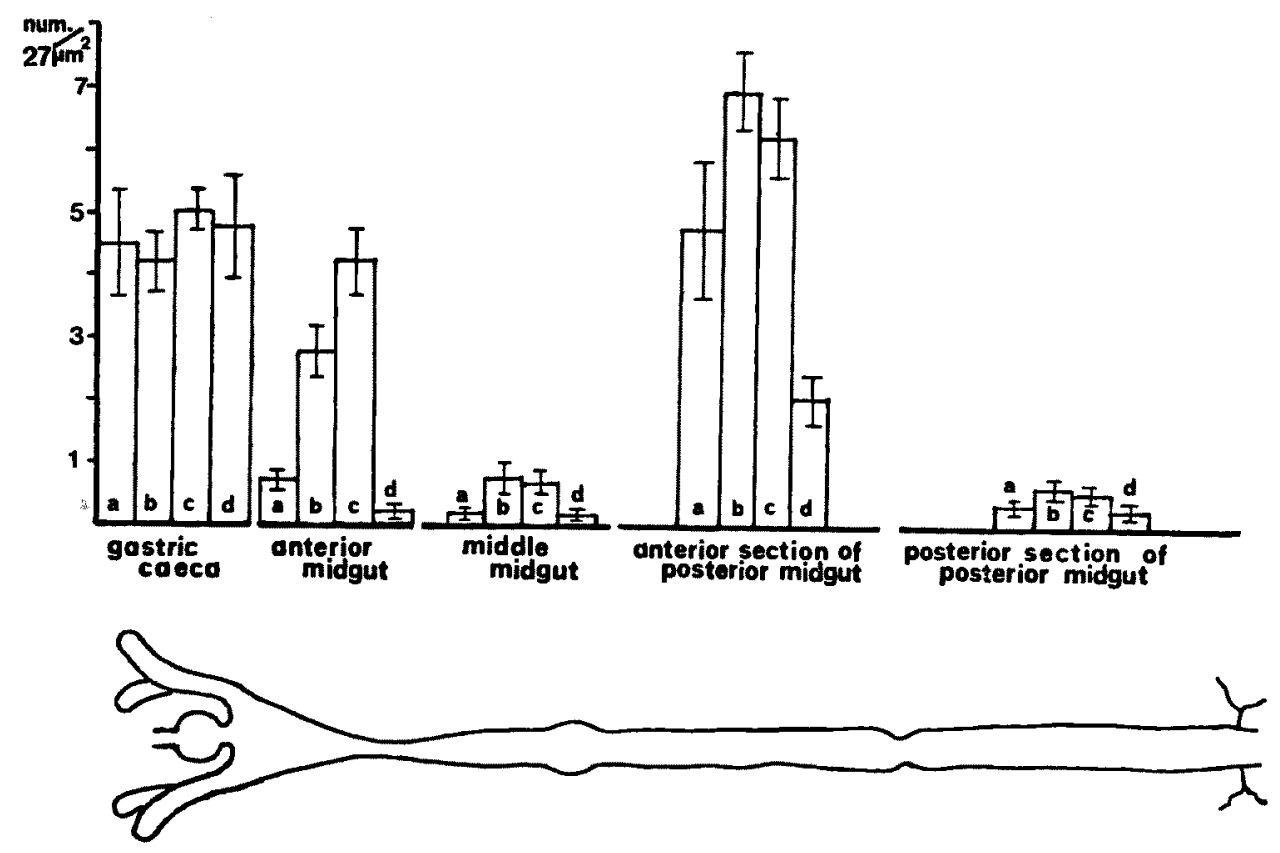

Fig. 1. Schematic drawing of Drosophila auraria midgut and means \pm standard errors of the number of the apical secretory granules of caeca and midgut cells of "normally fed larvae" (a) and larvae fed on a diet rich in starch (b), casein (c) and cholesterol (d) for $24 \mathrm{~h}$. The results are expressed as number $/ 27 \mu \mathrm{m}^{2}$.

Larvae fed on a diet rich in casein for $24 \mathrm{~h}$, also showed a great increase in the secretory granules of the anterior midgut, while a lower increase was observed in the anterior section of the posterior midgut and in the gastric caeca, as compared to the "control larvae". Finally, a diet rich in cholesterol resulted in a great decrease of the number of the secretory granules in the anterior midgut and the anterior section of the posterior mdgut (Fig. 1, Table 2). In contrast, the number of the secretory granules of the gastric caeca cells and of the other midgut regions remained constant. 
Although the different purpose of the present study, it worths mentioning that in the case of the larvae fed with cholesterol an increase in the lipid inclusions in the anterior and posterior midgut cells was detected and a great development of smooth endoplasmic reticulum in the anterior midgut cells (Fig. 3), in contrast with the control larvae that presented only rough endoplasmic reticulum.

Table 2. Mean values and standard errors of the number of the apical secretory granules of caeca and midgut cells of "normally fed larvae" and larvae fed on a diet rich in starch, casein and cholesterol for $24 \mathrm{~h}$.

The results are expressed as number $/ 27 \mu \mathrm{m}^{2}$

\begin{tabular}{lccccc}
\hline & $\begin{array}{c}\text { Gastric } \\
\text { caeca }\end{array}$ & $\begin{array}{c}\text { Anterior } \\
\text { midgut }\end{array}$ & $\begin{array}{c}\text { Middle } \\
\text { midgut }\end{array}$ & $\begin{array}{c}\text { Anterior } \\
\text { section of } \\
\text { posterior } \\
\text { midgut }\end{array}$ & $\begin{array}{c}\text { Posterior } \\
\text { section of } \\
\text { posterior } \\
\text { midgut }\end{array}$ \\
\hline $\begin{array}{l}\text { Normally fed larvae } \\
\text { Larvae fed on a diet rich in } \\
\text { starch }\end{array}$ & $4.45 \pm 0.82$ & $0.74 \pm 0.17$ & $\mathbf{0 . 2 2} \pm 0.09$ & $4.84 \pm 1.08$ & $0.47 \pm 0.13$ \\
$\begin{array}{l}\text { Larvae fed on a diet rich in } \\
\text { casein }\end{array}$ & $5.03 \pm 0.41$ & $4.23 \pm 0.57$ & $0.71 \pm 0.18$ & $6.36 \pm 0.63$ & $0.68 \pm 0.18$ \\
$\begin{array}{l}\text { Larvae fed on a diet rich in } \\
\text { cholesterol }\end{array}$ & $4.81 \pm 0.79$ & $0.24 \pm 0.13$ & $0.17 \pm 0.12$ & $2.02 \pm 0.39$ & $0.43 \pm 0.19$ \\
\hline
\end{tabular}

\section{Discussion}

The mechanism of digestive enzyme control in insects has not been fully clarified as yet. However, recent studies of different enzymes in insects reared on different diets have supported the existence of a secretagogue mechanism controlling the digestive enzyme productivity (Gooding 1975, Lehane 1977, Walker et al. 1980, Baker 1982, Houseman and Downe 1983). According to this theory, the quantity of a specific nutrient, rather than the total bulk of the food determines the production of the appropriate enzyme. In the case of Drosophila melanogaster, data supporting this theory has been presented by Hosbach et al. (1972) who found that larvae fed either on casein or starch diets have protease or amylase activity levels in proportion to the quantity of the appropriate substrate. Walker et al. (1980), also reported that leucine aminopeptidase activity in larvae increased in response to increased concentrations of dietary protein.

Preliminary evidence supporting the digestive enzyme origin of the secretory granules has been found in Drosophila auraria (Dimitriadis 1985) where the number of these granules of midgut and caeca cells decreased after $3-4 \mathrm{~h}$ of starvation. This seems to agree with previous results, where was shown that starvation affected the digestive enzyme production (Day and Powning 1949, Rao and Fisk 1965, Ferreira and Terra 1982) and especially with the fact that in the midgut of Drosophila melanogaster, the activity of proteolytic and amylolytic enzymes decreased $50 \%$ and $30 \%$ respectively after $4 \mathrm{~h}$ of starvation (Hosbach et al. 1972). In the present study, the observations on Drosophila auraria support that there is a relation between the various diets used and the change of the secretory granules produced by the different regions of the midgut. Therefore, if the theory of enzyme dependence on a secretagogue stimulus is valid, our results reveal one more evidence that these 
secretory granules contain digestive enzymes.

Concerning the participation of the various midgut regions in the digestion of the three different diets used, it could be concluded that the anterior midgut and the anterior section of the posterior midgut can be considered as the main sites of
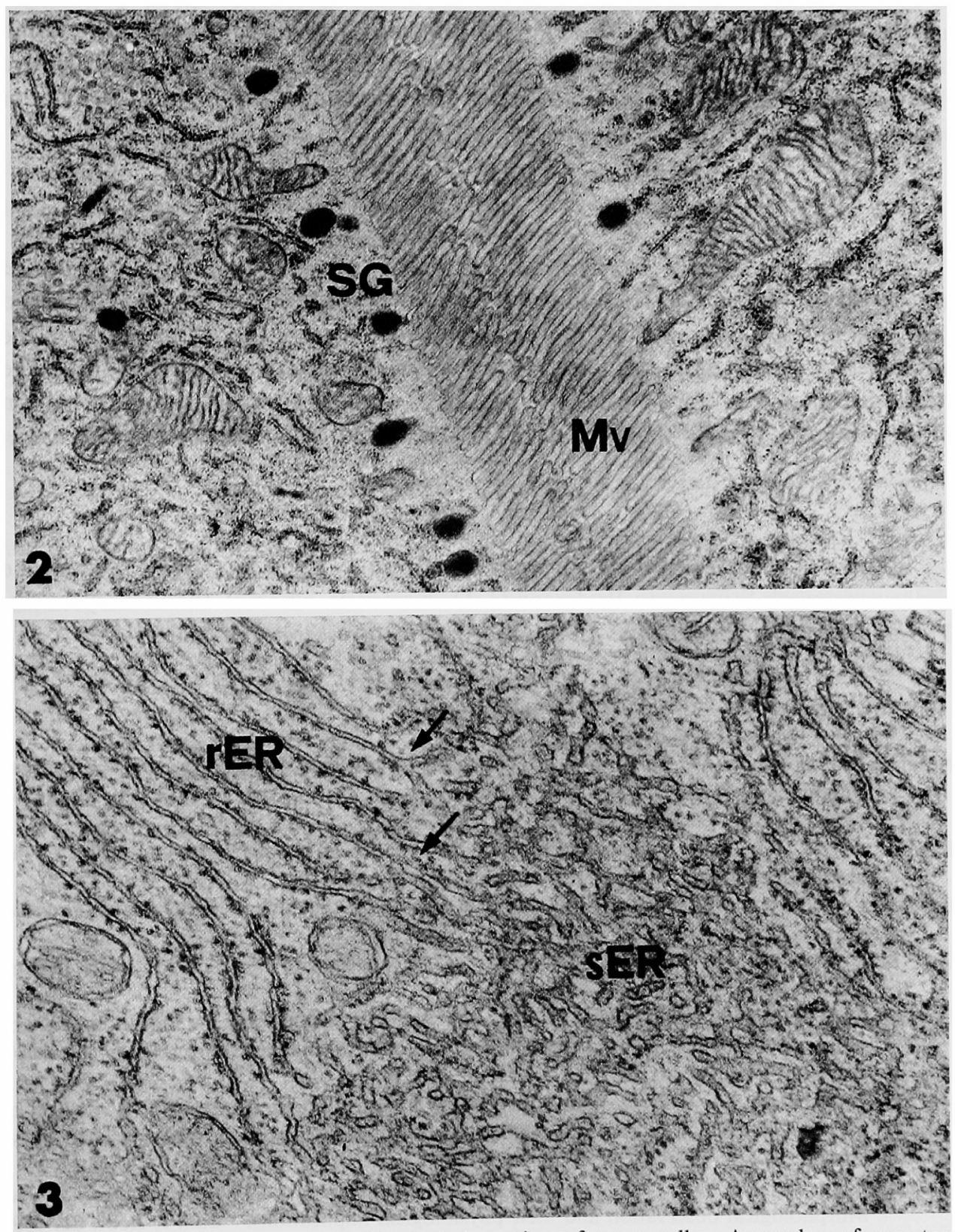

Figs. 2-3. 2, "Normally fed larvae". Apical portion of caeca cells. A number of secretory granules (SG) were observed near the microvilli (Mv), i.e., just prior to their secretion. $\times 20,000$. 3 , larvae fed on a diet rich in cholesterol. A great development of smooth endoplasmic reticulum (sER) was detected in cell of anterior midgut. The arrows show points of transition of rough $(\mathrm{rER})$ to smooth endoplasmic reticulum cisternae $(\mathrm{sER}) . \times 35,000$. 
starch as well as casein digestion. This is because these are the principal regions of the midgut, that react to these substrates dy increasing the number of secretory granules. In the case of cholesterol, however, we can not reach clear conclusions. In the case of starch and casein the present evidence is in agreement with previous results on Drosophila according to which amylase is detected only in the anterior and posterior midgut of the larvae (Abraham and Doane 1978) and of the adult insect (Powell and Lichtenfels 1979). In addition leucine aminopeptidase is absent from gastric caeca (Walker et al. 1980) and has its strongest activity in the anterior section of posterior midgut of the larvae (Dimitriadis and Kastritsis 1985).

\begin{abstract}
Electron microscopic examination and morphometric evaluation of Drosophila auraria larvae fed on diets rich in starch, casein or cholesterol for $24 \mathrm{~h}$ indicated that each of these nutrients influence, perhaps upon a secretagogue mechanism, the number of secretory granules which are produced in several midgut regions. The relation of these secretory granules to digestive enzymes as well as the participation of the midgut regions in the digestion of starch, casein and cholesterol is discussed.
\end{abstract}

\title{
Acknowledgements
}

The work reported in this paper was supported by grant No. 1/36 178 from the Volkswagenwerk Stiftung to Professor C. D. Kastritsis whom I thank very much. The author, also, thanks Ms. E. Kouskounelou for secretarial help.

\section{References}

Abraham, I. and Doane, W. W. 1978. Genetic regulation of tissue-specific expression of Amylase structural genes in Drosophila melanogaster. Proc. Natl. Acad. Sci. U.S.A. 75: 44464450.

Baker, J. A. 1982. Synthesis of endopeptidases and exopeptidases in actively feeding larvae of the black carpet beetle. J. Georgia Entomol. Soc. 17: 221-228.

Beadle, D. J. 1971. The localization of alkaline phosphatase in the midgut epithelium of Carausius morosus. Histochemie 27: 370-372.

Day, M. F. and Powning, R. F. 1949. A study of the processes of digestion in certain insects. Aust. J. Sci. Res. 149(B. 2): 175-215.

Dimitriadis V. K. 1985: Effect of starvation on the secretory product and the morphological appearance of the infoldings of basal plasma membrane of midgut cells of Drosophila auraria larvae. Cytologia 50: 593-601.

- 1985. Ultrastructural analysis of the midgut of Drosophila auraria larvae. Distribution of alkaline phosphatase, acid phosphatase, leucine aminopeptidase, and glycogen. Cytologia 50: $689-700$.

- and Kastritsis C. D. 1984. Ultrastructural analysis of the midgut of Drosophila auraria larvae. Morphological observation and their physiological implications. Can. J. Zool. 62: 659669.

Eguchi, M., Iwamoto, A. and Yamauchi, K. 1982. Interrelation of proteases from the midgut lumen, epithelia and peritrophic membrane of the silkworm, Bombyx mori L. Comp. Biochem. Physiol. 72A: 359-363.

Ferreira, C. and Terra, W. R. 1980. Intracellular distribution of hydrolases in midgut caeca cells 
from the insect with emphasis on plasma membrane-bound enzymes. Comp. Biochem. Physiol. 66B: $467-473$.

- and - 1982. Function of midgut caeca and ventriculus: Microvilli bound enzymes from cells of different midgut regions of starving and feeding Rhynchosciara americana larvae. Insect. Biochem. 12: 257-262.

-, Ribeiro, A. F. and Terra, W. R. 1981. Fine structure of the larval midgut of the fly Rhynchosciara and its physiological implications. J. Insect Physiol. 27: 559-570.

Gooding, R. H. 1975. Digestive enzymes and their control in haematophagus arthropods. Acta Trop. 32: 96-111.

Hosbach, H. A., Egg, A. H. and Kubli, E. 1972. Einfluss der Futterzusammensetzung auf Verdaungsenzyme-Aktivitäten bei Drosophila melanogaster-larven. Rev. Suisse Zool. 79: 1049_ 1060.

House, H. L. 1974. Digestion. In The Physiology of Insecta (Ed. by Rockstein, M.), pp. 63-117. Academic Press, New York and London.

Houseman, J. C. and Downe, A. E. R. 1981. Exoproteinase activity in the posterior midgut of Rhodnius prolixus Stal. (Hemiptera: Reduviidae). Insect Biochem. 11: 579-582.

- and - 1983. Activity cycles and the control of four digestive proteinases in the posterior midgut of Rhodnius prolixus Stal. (Hemiptera: Reduviidae). J. Insect Physiol. 29: 141-148.

Karnovsky, M. J. 1965. A formaldehyde-glutaraldehyde fixative of high osmolarity for use in electron microscopy. J. Cell Biol. 27: 137A-138A.

Lehane, M.J. 1977. An hypothesis of the mechanism controlling proteolytic digestive enzyme production levels in Stomoxys calcitrans. J. Insect Physiol. 23: 713-715.

Palade, G. E. 1975. Intracellular aspects of the process of protein synthesis. Science (Washington, D. C.) $189: 347-358$.

Powell, J. R. and Lichtenfels, J. M. 1979. Population genetics of Drosophila amylase. Genetic control of tissue-specific expression in D. pseudoobscura. Genetics 92: 603-612.

Rao, B. R. and Fisk, F. W. 1965 . Trypsin activity associated with reptoductive development in the cockroach, Nauphoeta cinerea (Blattaria). J. Insect Physiol. 11: 961-971.

Rudin, W. and Hecker, H. 1982. Functional morphology of the midgut of a sandfly as compared to other hematophagous Nematocera. Tissue and Cell 14: 751-758.

Terra, W. R., Ferreira, C. and De Bianchi, A. G. 1979. Distribution of digestive enzymes among the endo- and ectoperitrophic spaces and the midgut cells of Rhynchosciara and its physiiological significane. J. Insect Physiol. 25: 487-494.

Walker, V. K., Geer, B. W. and Williamson, J. H. 1980. Dietary modulation and histochemical localization of leucine aminopeptidase activity in Drosophila melanogaster larvae. Insect Biochem. 10: 543-548. 